\title{
EVOLUTION OF TRADITIONAL BANKS' BUSINESS MODELS
}

\author{
PANOVA Galina $\mathbf{S}^{\mathbf{1}}$. \\ ${ }^{I}$ Moscow State Institute of International Relations (MGIMO University) (RUSSIA) \\ E-mail:gpanova@mail.ru
}

\begin{abstract}
The article considers topical issues of how banks are developing in the new realities of the digital economy, and presents the results of research on theoretical and practical aspects of banks' business models evolution. The methodology uses such approaches as scientific abstraction, system and factor analysis, methods of grouping, detailing, and synthesis. The topic is relevant for banks first of all from the economic science point of view, since until now the conceptual apparatus of not only the types of bank business models but also the definition of bank business models and their ecosystems remain controversial. However, in practice the applying of new strategic solutions is needed to solve the triune task: to ensure profitability of banks' business while maintaining liquidity and minimizing risks. The obtained results allowed us to reveal the important role of the banks' business models innovative transformation, as well as to reveal the tendency of improving the intermediary function of banks on the modern stage of digital technologies' development. The article substantiates the need to develop new approaches to administering business processes, expanding banking activities using digital platforms, and reveals the problem that requires the speediest solutions in developing regulation standards for financial ecosystems.
\end{abstract}

Keywords: innovation, technology, financial market, banks, business models, digital platform, ecosystem.

JEL:G21

DOI: $10.5937 /$ intrev2102148P

UDC: 005.591.6:336.71

COBISS.SR-ID 43529481 


\section{INTRODUCTION. NEW TRENDS}

Problems of the banks' evolution have been agitating the minds of scientists and practitioners for centuries. In the 1970s and 1980s scientists argued that banks were losing their influence and their role in the economy was sharply reduced under the influence of scientific and technological progress, active automation of bankers' work, saturation of bank branches with computer equipment, and the development of new technologies. And at the beginning of the 21 st century the discussions regarding promising banks' business models have intensified again under the influence of the process of the internationalization and deglobalization of the world financial markets, global financial crises (2008-2009), the oil crisis of 2020 and the Covid-19 coronavirus pandemic.

The increasing risks of inflation negatively affect the world economy. One of the new trends in the financial markets, which were influenced by macroeconomic factors, technological challenges and increasing regulatory burden on banks, was the changes in the economy in the context of the Fourth industrial revolution $[12,13,14]$. According to the latest data, the penetration of information technology into the financial industry in a number of countries was as follows: China - 60\%, the Russian Federation $43 \%$, Kazakhstan - 21\%. China, Russia, Great Britain, Canada, countries of the European Union and EAEU are actively implementing their pilot projects to introduce state digital currencies on their territory and are discussing the consequences of these decisions for the world financial markets $[4,5,9]$.

The global fintech industry is growing rapidly, using technological innovations to capture market share from existing companies in many financial services sectors. Whereas until recently fintech has focused mainly on the development of payments, direct (P2P) lending and crowd funding sectors, in the past decade there has been an increase in capital markets operations. New fintech solutions have faced banks around the world. In these conditions banks began to compete with fintech companies and develop cooperation with them.

During the technological transformation at each stage of value creation there are a significant number of suppliers of high-quality personalized financial products and services offered to the market at low prices. Competition with such companies is difficult for traditional banks and, in order not to lose out in competition to new market participants they are forced to optimize the supply of their products, concentrating on areas where they have a competitive advantage or strategic importance.

The global fintech industry is developing rapidly, using technological innovations to capture market share from existing market participants in many financial services sectors. The main innovative areas of financial engineering include: Cloud technology; Process and service externalization; Robotic Process Automation (RPA); Advanced Analytics; Digital transformation; Blockchain; Smart contracts; Artificial Intelligence (AI); Internet of Things. [8,15].

Fintech companies aim to capture at least $33 \%$ of the traditional banking business. Citibank predicts that by 2025 , the growing impact of financial technology could lead to job losses for $30 \%$ of bank employees. [11,16,17].

The big banks offer huge opportunities for fintech companies by giving them access to global financial markets while transforming their own business models. Confirmation of these changes was the rapid development of the so-called "shadow" (unregulated) banking system, whose participants perform intermediary and credit functions for households and companies often faster and at less cost than traditional banks. However, innovation, while supporting the efficiency of financial intermediaries, has at the same time led to an increase in systemic risks that materialized during the global financial and banking crisis of 2008-2009 and the Covid-19 coronavirus pandemic. [10,13].

Currently there is an active search for new and transformation of traditional banks' business models on the basis of digitalization; and the formation of new types of platform-type companies, which are based on a wide variety of partners and customers that did not exist before the ubiquitous spread of the Internet and smartphones.

In economic science, new terms are emerging to characterize the business models of banks - e.g. nonbanks, hybrid banks, aggregators, platforms, infrastructure providers, ecosystems. Their advantages and disadvantages are discussed in comparison with traditional business models, but emphasize the need for banks to perform their basic functions under the supervision of financial market regulators. [11,9]. 
In these conditions, the transformation of the banking industry, the change of the classical bank's business model, which is gradually gaining new features of digitalization, the formation of new business models and ecosystems form the basis for discussions about the prospects of banks and national banking systems in the near and distant future.

\section{METHODOLOGY}

The methodology uses such approaches as scientific abstraction, system and factor analysis, methods of grouping, detailing, and synthesis; comparison methods, benchmarking of market practices and recommendations of international consultants $[1,3,6,7]$ and other theoretical and empirical studies.

The analysis was based on reports and other materials of the World Bank, Bank for International Settlements, Bank of Russia, commercial banks and consulting companies.

The main objectives of the article are to reveal a modern problem of evolution of traditional banks' business models and to show the role of banks in the economy in future.

The analysis of international experience and Russian practice shows that there is no single approach to determining the bank's business model now. For example, the International Standard for Integrated Reporting (p.4B) defines an organization's business model as "a system of resource transformation through its commercial activities into products and results aimed at achieving the organization's strategic goals and creating value over the short, medium and long term", thus highlighting key elements of the business model - resources, business, products and results. And in IFRS 9 "Financial Instruments" the business model is characterized as the way in which an enterprise manages its financial assets in order to generate cash flows and allocates three types of business models: (a) focused on holding an asset to receive cash; (b) to withhold an asset to receive cash and sell an asset (hold to collect and sell), c) other business models.

The Bank for International Settlements (BIS) uses only a range of products as a criterion for classifying banks' business models. McKinsey identifies two criteria for grouping banks' business models: the type of products/services and the way they are sold.

Banks in the changing world of financial intermediation highlight the following promising business models: 1) the innovative, end-to-end ecosystem orchestrator; 2) Low-cost manufacturer; 3) the bank is focused on specific business segments; 4) the traditional but fully optimized and digitized bank. We consider this approach as the most complete and correct.

Banks at the initial stage of transformation and adaptation of their business models to the conditions of the new economic reality begin to make daily operations in digital mode (for example, to pay for the services of mobile operators and the Internet, payment of utilities, rent, etc.). Banks provide new products and services for their customers (opening accounts, accepting deposits and issuing loans, issuing plastic cards, etc.). Bank offices are functionally adaptable to the global digitization of the banking industry. The transition to the paperless branch format is carried out, where the client confirms the transaction and signs the documents in the bank's mobile application in the presence of the employee who forms the document and its digital image. Information is provided to the customer remotely in a visual format. Then the client can remotely apply for a bank loan, open his personal mortgage office, get the approval of the loan, after which the bank will transfer funds to the borrower's account. Customers save time and money by receiving on-line information about banks' products and services and have an opportunity to purchase them remotely.

Now banks determine the type of their business model taking into account the level of market competition, the degree of its monopolization, the level of technical and technological equipment of the bank and its competitors, professionalism of banks' employees and ability of customers to use banks' innovations. Nature and scope of banks' activities, profitability, specialization, competitive advantages, as well as the need to comply with regulatory requirements have a great influence on the choice of a promising business model. After the global financial crisis (2008-2009) regulators introduced new requirements aimed at maintaining the stability of banks, including capital adequacy and liquidity levels. This affected the profitability of banks and largely determined the range of products they offered, which in turn predetermined the emergence of new business models. The use of crowd funding and crowd investing on the basis of P2P platforms offered an alternative to traditional banking. As a result now all banks can be divided into two groups: 1) traditional (classic) and 2) banks with new business models (among them are the so called hybrid and neo-banks models). Experts consider them promising, as these banks offer low 
tariffs, flexible and personalized service to customers, convenient mobile banking service, which allows them to attract more customers and receive higher profit. The new models also include: infrastructure banks for fintech companies and/or banks; aggregator banks; platform-based business models (remote customer identification platforms, fast payment platforms, financial products and services marketplace platforms, and new platforms based on distributed ledger technologies and cloud technologies). The largest and most successful banks create the so-called ecosystems. [11, 16]

\section{RESULTS}

\section{RUSSIAN CASE}

The traditional banking business model is to provide services for retail and corporate customers. Our analysis of the development of banks in Russia with focus on institutional and functional approaches has shown that banks are the dominant element of Russian financial market. The share of their assets in the total assets of financial intermediaries exceeds $80 \%$. At the same time, the Russian financial market is actively consolidating the banking sector (table 1). In the last 10 years the number of banks reduced by almost three times. According to the Bank of Russia, 366 banks were registered in Russia as of 01.01.2021.

Table 1. Russian Banking System Indicators, 2011-2019 (January, 1)

\begin{tabular}{|c|c|c|c|c|c|c|c|c|c|}
\hline & 2011 & 2012 & 2013 & 2014 & 2015 & 2016 & 2017 & 2018 & 2019 \\
\hline \multicolumn{10}{|l|}{ Banks ranked by assets $(\% \%)$} \\
\hline Top 5 & 47,7 & 50,0 & 50,3 & 52,7 & 53,6 & 54,1 & 55,3 & 55,8 & 60,4 \\
\hline $6-20$ & 20,9 & 20,2 & 19,5 & 19,8 & 21,5 & 21,6 & 22,8 & 23,5 & 21,2 \\
\hline $21-50$ & 11,6 & 11,0 & 11,6 & 11,1 & 10,6 & 11,3 & 10,6 & 10,8 & 9,8 \\
\hline $51-200$ & 13,7 & 13,0 & 12,9 & 12,2 & 10,8 & 10,2 & 9,4 & 8,4 & 7,6 \\
\hline $201-500$ & 4,7 & 4,6 & 4,5 & 4,1 & 3,0 & 2,5 & 1,9 & 1,0 & 1,0 \\
\hline Number of banks & 1012 & 978 & 956 & 923 & 834 & 733 & 623 & 561 & 484 \\
\hline Assets per bank, billion rubles & 33,4 & 42,6 & 51,8 & 62,2 & 93,1 & 113,2 & 128,5 & 151,9 & 194,4 \\
\hline Capital adequacy, H1, \%* & 18,1 & 14,7 & 13,7 & 13,5 & 12,5 & 12,7 & 13,1 & 12,1 & 12,2 \\
\hline Reserves for possible losses, $\%$ liabilities & 6,5 & 5,6 & 4.9 & 5.0 & 5.2 & 6,5 & 7,0 & 8,1 & 8,0 \\
\hline
\end{tabular}

Source: Bank of Russia

The largest Russian banks - Sberbank and VTB were ranked 67th and 116th, respectively, in 2019 in the International rankings of globally systemically important banks.

Sberbank is currently the largest banking group in Central and Eastern Europe. In Russia it serves 110 million individuals and 1 million companies; operates in 22 countries and has more than 11 million customers abroad. The share of foreign assets of the bank is $14 \%$ in the total amount. The creation of a foreign network is conditioned by the need to provide banking services to Russian companies abroad, diversify the business and increase profitability through operations in high-margin markets. Sberbank plans to resume expansion into the Western European markets of France, Germany and Great Britain after the lifting of sanctions.

VTB, the second largest bank in Russia, has foreign subsidiaries in New Delhi (India) and Shanghai (China) and offices in Beijing (China) and Milan (Italy). The Group consists of: VTB Bank (Austria) AG, VTB Bank (Deutschland) AG, JSC VTB Bank (Armenia), VTB Bank (Kazakhstan), JSC VTB Bank (Ukraine), JSC VTB Bank (Georgia), VTB Capital plc. (UK), VTB Bank (France) S.A., VTB Bank (Belarus), BANCo (Cyprus), VTB Bank (Azerbaijan),VTB Bank (Belgrade), Vietnam-Russia Joint Venture Bank. The competitive advantages of VTB Group are the flexible business model, the universal nature of the Group's business, the established brand and strong ties with leading Russian companies, as well as the professional composition of managers and the ability to serve customers around the world. The latter advantage is a key one. 


\section{ECOSYSTEMS AS BUSINESS MODELS OF MODERN BANKS}

The main approaches to define ecosystems are the following: a) business model with Bigtech companies as the core of the ecosystem; b) business model in which fintech start-ups are in the center of the ecosystem; c) business model in which the core of the ecosystem is the traditional financial intermediary. The last business model dominates in Russia. [3]. Sberbank and VTB Bank are bright representatives of this approach. Sberbank began to create ecosystem in 2014. Now it brings together dozens of partner companies from retail supermarkets to logistics companies, cinemas, etc. The evolution of the traditional Sberbank business model included the following steps [7]. A large-scale technological transformation and the development of the basis of the technology platform were set in 2014-2017. At that period Sberbank made the transition from the centralized automated systems to the banking platform, which involved the integration of infrastructure and the centralization of databases. The evolution of the platform for banking and non-banking services (internal cloud, cloud-ready applications, and single development environment) is dated by 2018 year. In 2019 Sberbank created a platform for the ecosystem (launch of the platform into industrial operation; platform with Cloud-native component for ecosystem). The priority for the 2022 year is $80 \%$ of customer operations should be transferred to the platform. Currently, Sberbank believes that AI-transformation is already yielding the first results. In 2020 the effect of the introduction of AI amounted to about $\$ 1$ billion. Approximately $40 \%$ of private client visits are handled by a chatbot. The volume of approved applications for fixed-term credit (the loan for 7 minutes) amounted to about 100 billion rubles.

The ecosystem uses targeted platforms (e.g. NLP, speech analysis, biometrics, etc.). During the corona crises pandemic in the Sberbank ecosystem there were its beneficiaries (Delivery Club, Okko, docdoc, DomClick.ru, SBERMARKET, take!) and affected services (Citi mobile, Rambler/cash, SBERFOOD). But overall, the financial situation in the Sberbank ecosystem in 2020 has improved (capital adequacy ratio raised to $13.31 \%$ and the ratio of loans and deposits was $93.5 \%$ ).

Systemically important Russian banks - VTB, Alpha Bank, Gazprombank, Rosbank, Rosselkhozbank - are currently implementing their projects of developing ecosystems [11]. However, this process carries many risks. The returns from nonbank businesses may be less, and later than the bank (which is at the center of the ecosystem) expects. At the same time, fintech companies are coming to financial wounds, which seek to expand the range of their customers, increase income and profitability of their business. For example, company Yandex confirmed at the end of 2020 its desire to create its own financial ecosystem and applied to the financial markets regulator to register 17 trademarks in banking, investment and insurance.

\section{CONCLUSIONS / RECOMMENDATIONS}

The speed of transformation of the banking sector often creates problems for regulators, who are forced to balance between the opposite goals: to maintain the stability of financial markets and stimulate the development of banks and other financial intermediaries. Analysis of Russian and foreign practice has shown that the main problem of the bank traditional business model is the following. Many banks have realized that cooperation with fintech companies is the key to survival and prosperity in the conditions of technological revolution and began to look for new approaches to the development of their business, to build new business models.

Bank of Russia, as financial regulator, develops market infrastructure, coordinates activities of financial agents and state institutions. The key features of the Bank of Russia strategy in this area are: legal regulation, information infrastructure and information security. "The main areas of financial technology development for the period 2018-2020" are synchronized with the national program "Digital Economy of the Russian Federation" and other projects in the field of financial technology development. [2].

The implementation of these projects contributes to the digitization of financial markets and the availability of financial services to the people in all regions of the country. Bank of Russia's main objectives in implementing financial technology policy documents include promoting competition in the financial market, improving accessibility, quality and range of financial services, reducing financial risks and costs, and improving the competitiveness of Russian technologies in general. The Bank of Russia sees banks in the long term as a driver of economic growth and the development of financial services. Currently, the Bank of Russia is actively stimulating the introduction of new technologies, including the creation of the so-called end-to-end customer ID and platform for cloud services. Distributed registry technology is presented in the Bank of Russia's strategy primarily by the Master Chain platform, which the Bank is 
developing in conjunction with the FinTech Association. Pilot projects are under way to account for electronic invoices, digital letters of credit and digital bank guarantees.

The development of digital technologies is accompanied by the growth of cyber threats, which require the regulator and financial intermediaries to quickly prevent or minimize them. To this end, the Bank of Russia pays special attention to the legal regulation of the use of breakthrough technologies and their direct implementation and development in the Financial Market of Russia and the EAEU space. In particular, new digital tools and services are being tested at RegTech (regulatory sandbox - test site), which is a tool to quickly check the consequences of innovations in the financial market, analyze risks and form proposals to change the current regulatory framework, which allows to select those projects that are important for the population and the national economy. The introduction of SupTech (Supervision Technology - Surveillance Technology) allows the Bank of Russia to more actively analyze the affiliation of borrowers, determine the current demand for cash and its prospects analyze and maintain the financial stability of banks and identify fraudulent transactions. At the same time, the Bank of Russia promotes the electronic interaction between government agencies and financial intermediaries and their clients, as well as improves the quality of new products and services, creates conditions for improving financial literacy of the population.

At the international level, new regulatory approaches (e.g., the EU's so-called "open banking" initiative - the PSD2 directive, which obliges credit organizations to share customer information with service providers at the request of the consumer), initiatives to simplify customer authorization processes, as well as favorable macroeconomic conditions and increased use of technology have led to the emergence of new financial intermediaries and increased the need to transform the bank's traditional business model. On the other hand, the international banking standards set out in the Basel agreements to ensure the stability of banks require them to create additional capital buffers, which lead to higher business costs and the displacement of highly risky assets outside the banking industry. Other directives (e.g. MIFID II financial instruments markets directive, aimed at protecting investors and standardizing financial institutions in the EU and restoring industry confidence) suggest that banks' approaches to their business strategies change in the new environment.

The future of banks is being shaped today. Influenced by technological innovations, the business model of banks is changing dramatically. Banks with great technological potential use fundamentally new business models analyze the activities of aggregators, marketplaces, ecosystems and on their basis create technological services for customers. Banks operating in the new paradigm of digital banking are changing their operations and transforming the landscape of financial markets as a whole. This study analyzes the current situation and the prospects for the development of banks' business models, taking into account the impact of systemic and individual risks.

Studying the evolution of traditional banks' business models allowed us to assess the current realities of the development of Russian banks, identify barriers and the promising areas for banks' business development in the era of the Fourth industrial revolution. An explanation for organizational changes in the banking industry, confirmation of these changes was the rapid development of so-called "digital platforms" and "ecosystems" whose participants perform intermediary financial services for private clients and companies much faster and cheaper than traditional banks. However, while the benefits of innovation improve the efficiency of banks, significant increases in systemic and other risks must also be taken into account. The following conclusions can be drawn in this regard.

The development of financial technologies for banks becomes a fundamental direction to change their business models and develop the financial market as a whole. Creation and development of ecosystems have both positive and negative aspects. The increase in income and value of banks, the decrease in the cost of attracting funds and customers, increasing their loyalty can be attributed as positive aspects. The negatives are: reduction of competition or even monopolization of the market, as large banks may restrict the access of other financial market participants to the distribution channels of products and services; creating non-market competitive advantages for those organizations that have gained access to the network under the bank's brand; strengthening the position of the major ecosystem banks-administrators; creating obstacles to the growth of financial service providers, which have limited access to the ecosystem. The systemic risks of the ecosystem should not be passed on to the customers of the ecosystem-organizer bank. Obviously, the client should not suffer because individual members of the ecosystem (not banks) have specific risks and/or low yields, etc.

The regulation of ecosystems has also not yet been unambiguously defined. Therefore, the problem of regulating the activities of banks, which have chosen the strategy of development of their business in the 
paradigm of the ecosystem, in our opinion, should be considered from the point of view of differentiated supervision. They need to introduce deeper consolidated supervision and regulation, as the actual merger under a single brand of the bank of companies from different sectors of the economy is creating new risks that can have a significant impact on the financial stability of the group and the financial market as a whole. The regulation of digital ecosystems (including bank-based and fintech-based companies) needs to be studied at the global and national levels, which is important to maintain competition and eliminate any discrimination against ecosystem users.

In general, it is almost impossible to draw an unambiguous conclusion in favor of a particular business model of the bank, as the choice of business model for each bank is different, as each bank operates in the unique conditions of its market (in terms of competition, specialization, quality of the client base, structure and quality of the portfolio, the level of training of staff, etc.) and determines the prospects of its chosen business model. In the future, it is expected that in the process of digital transformation of banks' business models will benefit the entire financial market, which will become more transparent, efficient and stable.

At the same time it is obvious (at least in Russia) that the role of banks in the national economy is not declining, but rising. Sberbank, for example, was highly involved in the process of the National Strategy for the Artificial Intelligence Development, approved by the President of the Russian Federation.

\section{REFERENCES}

[1] Accenture - Platform Banking: A Business Model for the Digital Age, October 2018.

[2] Bank of Russia. (2018). Main Directions of the Financial Technologies Development for the 2018-2020 Period

[3] Banks in the Changing World of Financial Intermediation (2018). McKinsey Report.

[4] Chuen, D. and Deng, R. (2017). Handbook of Block chain, Digital Finance, and Inclusion. Academic Press

[5] Digital ruble. Report for Public Consultation. (2020). - Bank of Russia.

[6] Financial Conduct Authority. (2017). Strategic Review of Retail Banking Business Models: Purpose and Scope. pp. 5-6.

[7] Gref, G. (2019) Transformation of Sberbank is an Eternal Process. https://www.forbes.ru/biznes/387895-german-gref-transformaciya-sberbanka-eto-vechnyy-process

[8] Gutbrod M. (2020). Digital Transformation in Economy and Law. Digital Law Journal, 1(1), pp. 12-23.

[9] International Organization of Securities Commissions. Consultation Report on the Issues, Risks and Regulatory Considerations Relating to Crypto-Asset Trading Platforms (2019).

[10] King B. (2020). Bank 4.0, Banking Everywhere, Never at a Bank. John Wiley \& Sons.

[11] Panova G. (Ed.) (2021) Financial Markets Evolution: from the Classical Model to the Ecosystem. Challengers, Risks, New Features. Palgrave Macmillan.

[12] Schwab, K. (2017). The Fourth Industrial Revolution. New York: Crown Business.

[13] Schwab K., Malleret T. (2020). COVID-19: The Great Reset. World Economic Forum.

[14] Sologubova, G.S. (2019), Components of Digital Transformation. Yurayt Publishing House. Moscow. (In Russian).

[15] Stepnov I. (Ed.) (2021) Technology and Business Strategy. Digital Uncertainty and Digital Solutions. Palgrave Macmillan.

[16] Trushina K.V., Smagin A.V. (2019). Main Trends in the Development of the Banking System of the Russian Federation at the Present Stage. Banking services, № 12, pp.7-11.

[17] World Development Report 2019: The Changing Nature of Work. Washington, DC: World Bank.

\section{Article history:}

Received 12 April 2021

Revision 15 June 2021

Accepted 10 July 2021 